\title{
The Spatial Turn of Geography during the Edwardian Era
}

\section{Andreas Pichler}

\section{(2) OpenEdition}

1 Journals

Electronic version

URL: https://journals.openedition.org/ces/4904

DOI: $10.4000 /$ ces.4904

ISSN: 2534-6695

Publisher

SEPC (Société d'études des pays du Commonwealth)

\section{Printed version}

Date of publication: 1 April 2016

Number of pages: 93-108

ISSN: 2270-0633

\section{Electronic reference}

Andreas Pichler, "The Spatial Turn of Geography during the Edwardian Era", Commonwealth Essays and Studies [Online], 38.2 | 2016, Online since 06 April 2021, connection on 01 July 2021. URL: http:// journals.openedition.org/ces/4904 ; DOI: https://doi.org/10.4000/ces.4904

\section{(c) (i) $\odot$}

Commonwealth Essays and Studies is licensed under a Licence Creative Commons Attribution - Pas d'Utilisation Commerciale - Pas de Modification 4.0 International. 


\section{The Spatial Turn of Geography during the Edwardian Era}

Edwardianism scarcely exists as a geographical idea. Victorianism and especially Modernism have been given a good deal of geo-critical attention recently, but Edwardian still stands at most for a distinctive London architecture, a twilight age in politics, or perhaps an era in leisure fashion. The reason for its neglect may stem from the relative brevity of the Edwardian period stretching roughly from the turn of the last century to the beginning of WWI. Another reason might be that the geographies of Victorianism and Modernism cover the intervening years sufficiently to obviate the need for a geo-critical study of the era. This essay, therefore, explores the era's geographical spaces through a number of subject-matters in an attempt to show the period's genuine geography.

What do the discovery of the cycle of erosion, the development of the first London underground line, the coining of the term "geo-politics" and Howards End have in common? They are all part of Edwardianism, a period pertaining to the reign of Edward VII (1901-1910). In 1905, William Davis discovered the evolution of physical landforms through various stages of erosion. In 1900, the Central London Railway was the world's only public transport line to run completely underground. Emil Reich referred to "geopolitics" for the first time in his political treatise The Foundations of Modern Europe. And E.M. Forster created literary landscapes central to the Edwardian period with Howards End in 1910. These events might appear as isolated cases, they are nonetheless intrinsically related to Edwardianism.

More importantly, these events illustrate geographical phenomena. Davis's cycle of erosion concerns the sequential evolution of physical landforms. The inauguration of London's first underground line suggests trends in human geography and reflects the era's needs for urban and suburban transportation. Reich's lectures focus on the points of convergence between geography and politics. Finally, Forster's novel epitomizes the rapidly changing face of England's rural and urban milieus. These geographical phenomena reflect the physical, human, political and artistic changes taking place during the first decade of the twentieth century. ${ }^{1}$ In addition, they are closely linked to the idea of spatiality.

The present essay attempts to consider geography from a dialectical perspective proposing a geo-critical analysis of spaces shaping the Edwardian years. The reason for this stems in part from considerable advances in geographical knowledge at the turn of the last century, but also from the renewed interest in geography which distinguished this period from the Victorian age, when politics reigned as the dominant discipline in keeping with the Empire's historic expansion. ${ }^{2}$ Edwardianism certainly implies some temporality, which sets it apart from Victorianism and Modernism. Temporality is an

1. Due to the brevity of the essay, it was impossible to include a geo-critical discussion on the emerging question of gender in the political debate (the Suffragettes started in 1897) and in fiction, notably Forster's Maurice (1913, published posthumously in 1971).

2. Such an approach would rather be termed "Edwardian Geographies" and focus on the historical perspective of geography during the Edwardian period. Our focus therefore is on geography and not history. 
important factor in understanding Edwardianism as the term itself suggests a specific historical period. Yet, the time period roughly coinciding with the reign of King Edward VII abounds in geographical innovation. We, therefore, aim to show how geographies define the Edwardian years from about the end of the nineteenth century to the outbreak of the WWI, transforming spatial understandings of the Earth, revolutionizing human and political ways of life and shaping literary productions.

The works of two theoreticians of the Edwardian age provide the geo-critical basis for our spatial investigation, namely Georg Simmel and Andrew John Herbertson. Both theorists recognise the importance of studying geography through the lens of space, rather than observing political, economic or historical phenomena. Herbertson, for instance, identifies physical landforms in an effort to define natural regions in his "The Major Natural Regions: An Essay in Systematic Geography" (1905). Simmel, on the other hand, depicts in Die Großstädte und das Geistesleben (1903) (The Metropolis and Mental Life) the synthesis of physical and human aspects, which are, according to him, dialectically intertwined in the spaces of modern cities. While Herbertson relies on physical spaces, Simmel analyses the impact of the concrete environment upon the psychological state of human beings. Both authors describe the changing perceptions and conceptions of space before Bergson, Heidegger and Husserl discover the phenomenological and relational reevaluation of space. ${ }^{3}$

Comparatively little research has been done that locates Edwardianism within the geographical and spatial contexts. Most publications focus either on the Victorian age or on Modernist depictions of geography. ${ }^{4}$ Michel Collot, for instance, evokes geography's spatial turn in Pour une géographie littéraire (For A Literary Geography): "It would be better to speak about the decline of a historical model which had prevailed since the nineteenth century, a model based on the idea that progress is linear and continuous" (16, translation mine). Nevertheless, he locates the emergence of spatiality in geography a bit later, with the evolution of phenomenology in the 1930s and the post-modern trend after WWII. Likewise, Bertrand Westphal situates geography's spatial turn with the Einsteinian revolution in Geocriticism: Real and Fictional Spaces (9). And Eric Bulson thinks about novels, maps, and modernity in terms of the "spatial imagination" (11) focusing on representations in such authors as Melville, Joyce and Pynchon. It then becomes necessary to look at spatial conceptions of Edwardianism, to see whether geography implies the idea of space, and to locate geographical signposts. In this essay, we first link physical geography to the Edwardian years in order to explore some of the revelations concerning the Earth's material environment. Then, we shall identify how geography influences social, human and political ways of life, making it distinctively Edwardian. Finally, thinking geographically about Edwardianism implies recognition of the diverse ways in which literary texts portray these geographies. Following Forster's command in Howard's End "Only connect!" (159), we shall connect geography to literature. Mapping out various loci, we shall examine the way literature relies on geographies in regards to setting, character depiction and narrative through a selection of texts.

3. Bergson published the Essai sur les données immédiates de la conscience (Time and Free Will: An Essay on the Immediate Data of Consciousness) in 1927, Heidegger his Sein und Zeit (Being and Time) in 1927 as well, and Edmund Husserl the lectures Ding und Raum (Thing and Space) in 1907. Naylor.

4. Among the most relevant publications of Victorian geographies, see, for instance, Robert Mighall and Simon 


\section{The Physical Geographies of Edwardianism}

The aim of the first section is to build a bridge between two lines of research: physical geography and Edwardianism. Bridging these two fields of research is quite challenging as physical geography barely existed as a discipline during the Edwardian period. Compared to Germany, where Ritter and Humboldt left an important geographical heritage, the British relegated geography to commercial and political purposes, especially during the Victorian age of exploration and expansion. As a result, research in physical geography was neglected. Andrew Herbertson, however, justifies the need to study British landforms as "there is practically no systematic geography to bind us" (300).

Taking over the geography department at the University of Oxford after Mackinder, Herbertson set new parameters to define regions on a global scale in "The Major Natural Regions: An Essay in Systematic Geography." His regional concept centres on the spatial dimension of natural regions in an attempt to move away from the "commercial and political bias" (300). Attempting to answer the question "What is geography?" Herbertson proposes to look at definite natural divisions of the globe with the purpose of replacing "the purely political divisions of the world" (300). The geographical distribution of natural regions of the Earth then becomes the subject-matter of his theoretical perspective, in which "the ideal boundaries are the dissociating oceans, the severing mass of mountains, or the inhospitable deserts" (309). While political borders are well-marked lines, the "characteristics of one region melt gradually into those of another" (309). Far from seeing these regions as isolated areas, the author considers terrestrial macro-organisms as the guiding principles of regional spaces. The configuration of these spaces applies "horizontally and vertically" alike, because they are "determined by structure, the nature of the transforming processes, and the time during which they have been active" (302). Looking at configuration, climate, vegetation and density of population, the geographer is among the first to provide a spatial theory of the Earth's natural environment that takes into account the three-dimensionality of the time-space continuum. He seeks to explore the following key question:

What characteristics should be selected to distinguish one region from another? Size is not a sufficient guide, although it must not be neglected; neither is structure, nor even configuration, although this last suggests many important divisions of the Earth's surface, which must be taken into account in any rational classification. How can we determine the different orders of natural regions? The British Isles, for instance, form part of a much larger natural area, that of North-Western Europe, while they themselves can be analyzed into a number of sub-regions. (300)

Herbertson aims to redefine the geo-critical framework in that he proposes to look at the physical proportions of the terrain. He sees the environment "as part of a solid which comprises not merely the soil beneath, but the air above, with relations to other parts of the Earth" (301). The concept of the Major Natural Regions combines two aspects: one that looks at the complexities of "land, water, air, plant, animal, and man" as one regional unit. The second aspect concerns the regions" "special relationship as together constituting a definite characteristic portion of the Earth's surface" (301-2). Herbertson's "natural regions" synthesize micro- and macro regions of the Earth in an effort to describe the uniqueness of physical spaces. The importance of regarding spaces in this way becomes central in our analysis, as we attempt to illustrate the innovation of geographically-inspired spaces during the Edwardian years. 
Physical geography is largely absent in contemporary research, yet its diverse aspects became manifest in scientific studies during the first decade of the twentieth century. ${ }^{5}$ The sudden eruption of interest may in part be explained by recent discoveries in bio$\log y$ and botany. ${ }^{6}$ Also, new revelations around the permineralization of fossils led to a better understanding of rock formations and sedimentary layers. ${ }^{7}$ Additionally, the deterioration of the English atmosphere as a result of the Industrial Revolution triggered the systematic and scientific analysis of meteorology in order to make sense of such phenomena as smog. As a consequence, scientific fields such as meteorology, geology and geomorphology emerged during the Edwardian years.

In geomorphology, American geographer William Morris Davis developed the socalled "geographical cycle" around 1900. The concept related to the evolution and modification of continental landforms in which the different stages of erosion were believed to be parts of a cyclic process. Influenced by Darwin's theory of evolution, Davis looked at the analytical changes in topography to analyse patterns in the evolution of landscapes, patterns which nowadays are the standard. The denudation of landforms, the result of the geographical cycle, produces a featureless plain (peneplain) with few residential hills (monadnocks). ${ }^{8}$ Although Davis limited his erosion concept to humid climate conditions, his theory - also known as the "Davisian model" - has put geomorphology on the map of geophysical research on British landforms and influenced Britain's Ralph Bagnold in his scientific investigations of desert structures. Davis's legacy has reached far beyond specific climate zones in that it revolutionized the geo-physical spatial awareness around relief erosion in America as well as in the British Isles. After all, landform denudations ignore political divisions, and are intrinsically part of the evolutionary cycle of any concrete environment.

In geology, Horace Bolingbroke Woodward published in 1911 the History of Geology, the most comprehensive study of the geological history of the Earth's crust to this date. Woodward, one of the pioneers of the British Geological Survey, ${ }^{9}$ tries to understand "the successive changes in scene and life that have diversified [the earth's] surface in past times" (1). To him, the geological "story is written in the rocks, the minerals, and the fossils which form the outer portion, known as the earth's crust" (1). Retracing the history of the earth's lithosphere, the geologist captures in painstaking details "the fascinating subject of Earth Sculpture" (145). In addition, Woodward established around 1904 the most detailed and precise up-to-date geological map of Great Britain.

5. Franco Moretti, for instance, analyses in his Atlas of the European Novel the period from 1800 to 1900, focusing only on Victorian Britain. Nicolas Freeman investigates "representations of London between the death of Charles Dickens in 1870 and the outbreak of the First World War" (v) in Conceiving the City: London, Literature, and Art 1870-1914. Similarly, Andrew Thacker seems to move right into modernity in Moving Through Modernity when establishing a connection "between space, geography and movement, in modernist writing from around 1910 to 1939" (2).

6. Additional information on botany can be found in Alexander von Humboldt's Schriften zur Geographie der Pflanzen (Essay on the Geography of Plants).

7. Woodward in History of Geology provides an insightful outline of the history of the permineralization of fossils.

8. For more information on the geographic cycle, see:

<http://global.britannica.com/EBchecked/topic/134929/continental-landform/49819/Daviss-erosion-cycle-theoryand-related-concepts> (05 January 2016)

9. The history of the British Geological Survey can be traced at the following address: <http://www.bgs.ac.uk/ about/ourPast.html> (05 January 2016) 
In line with the sequence of chronostratigraphy, ${ }^{10}$ Woodward's historic map (since then geologically outdated) illustrates the different tectonic structures of Britain. From the Cambrian rocks in the north to the Carboniferous formations in the Midlands, where many coal beds fossilized carbon, and finally the sedimentary bagshot beds showing the London clay and chalk layers of the South Downs, various colours indicate the minerals present in the lithosphere. Interestingly, the map does not represent political and administrative divisions and borders, and focuses instead on geological data. From the Isle of Skye to the London basin, the demarcation lines merely refer to the limits of different tectonic rocks present on the surface areas. The spatial sense emerging in Woodward's map is singularly geological.

Finally, in meteorology, one of the youngest geographical disciplines, John George Bartholomew designed the Atlas of Meteorology in 1899. The atlas introduces for the first time the use of coloured contour layers to systematically chart meteorological data according

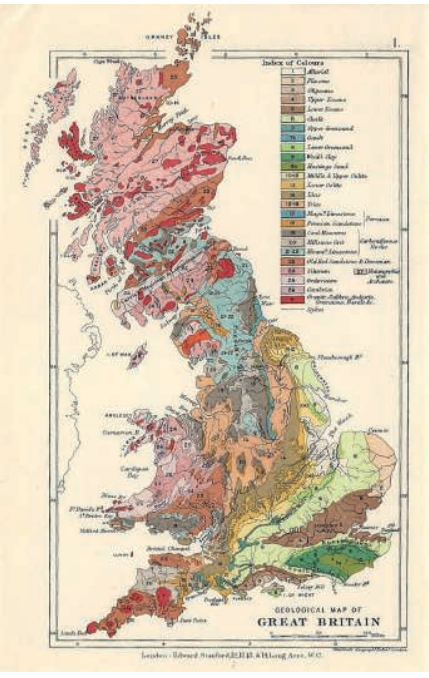

After Horace B. Woodward (1904). Stanford's Geological Atlas. (C) Ian West, 2000 .

(Permission granted)

to the physical landforms. Under the patronage of the Royal Geographical Society, Bartholomew records precipitation data from a large number of territories across the globe in what appears to be the most complete analysis of rainfall occurrences. Similar to Woodward, Bartholomew creates maps solely based on scientific meteorological data, ignoring political or historical facts. Not only does the meteorologist account for precipitation levels, but he also maps temperature, pressure, humidity, and winds in the atmosphere. $^{11}$

These advances in physical geography - whether in geomorphology, geology or meteorology - show a renewed sense of spaces distinctively Edwardian in that these spaces no longer referred to the politically-inspired Victorian age. The spatial newness lies in its geographical, three-dimensional aspects, aspects, which are likewise present in some noteworthy facets of human geographies.

\section{The Human Geographies of Edwardianism}

The very principles of human geography originate in the Edwardian period. Long before Vidal de la Blache published his Principles of Human Geography from 1910 onwards, Andrew Herbertson examined the effects of natural conditions on mankind. In Man and His Work: An Introduction to Human Geography (1899), the geographer analyses the interactions between the physical environment and human societies throughout a number of regions across the world:

10. Chronostratigraphy refers to the study of geological time and "a set of terms which are applied to bodies of rock which are laid down during these time intervals" (Whittow 85).

11. The meteorological phenomenon of "smog" manifested itself as one of the main causes of poor urban air quality in the latter part of the Victorian era. In an effort to combat air pollution, the British government published the Alkali Act in 1906. Reputedly coined in reference to the air pollution in London, and first attested in a paper read by Dr. H.A. des Voeux, treasurer of the Coal Smoke Abatement Society, the term "smog" appeared in the Journal of the American Medical Association on 26 August 1905. 
The world is the home of man. All that we learn of the physical features of the Earth, its climates, plants, and animals, is of practical importance because these things have made the human race what it is - here adventurous and progressive, there indolent and backward. Almost every problem in politics or history, if examined, carefully, would be found to depend at last on simple geographical conditions, and it is important that we should learn to look at geography in this living way. (1)

Herbertson studies the weight of the physical surroundings on mankind, outlining some of the complexities with regard to the condition and occupation of the human race. Based on travellers' narratives, he investigates the interaction of existing societies with such geographical spaces as tundras, temperate and tropical forests, steppes and savannas, hot deserts and mountains.

The link between geography and humans becomes particularly visible in Georg Simmel's Die Großstädte und das Geistesleben (The Metropolis and Mental Life). Simmel contributes to geocriticism in discussing the concrete and social structures of the metropolis. According to him, the metropolis affects mental life in such a way as to provoke people's responses to external forces. Sensual stimuli increase within the urban spaces when compared to rural settings, because the space of the metropolis creates a unique milieu:

The most significant essence of the metropolis lies in this functional magnitude beyond its physical boundaries: and this effectiveness reacts upon the latter and give to it life, weight, relevance and responsibility. A person does not end with the limits of his physical body or with the district to which his physical activity is immediately confined, but embraces, rather, the totality of meaningful effects which emanates from him temporally and spatially. In the same way the city exists only in the totality of the effects which transcend their immediate sphere. (33-4, translation mine)

The essence of the metropolis changes personal relationships; individuals develop a blasé attitude beyond mere physical spaces, become indifferent to themselves as well as to the area in which they live. This results in a reduced number of human interactions, a restriction leading paradoxically to a larger degree of personal freedom in comparison to the countryside. The metropolis frees the individual symbolically speaking from boundaries, and "the individual gains a freedom of movement" (27). The urban setting is full of "the wonders and comforts of space-conquering technique," (40) carrying populations "in a stream" (40). The city's material infrastructure, notably underground travel, provides the opportunity for spatial flows, as populations and goods move quickly and efficiently through the urban tissue.

Simmel's essay on the metropolis and mental life manifests itself as a spatial examination of geographical phenomena. First, the German philosopher examines the individual's position within the immediate surroundings. Then, he takes into account the tensions existing between country, city and suburbia. Finally, he stresses the importance of movement of commodities, people and ideas alike, as the flow transcends traditional boundaries of space. The geographical consideration of these spaces affects the mental dimension of humans, an aspect of his study which emerges as pertinent in our discussion of Erskine Childer and E. M. Forster. Before looking at the literary productions of these authors, let us first reflect on the human aspects of the changing British metropolis.

Human occupations of Edwardian Britain resulted in a number of unparalleled phenomena: the rise of the suburbs, the creation of administrative boroughs, the expansion 
of railway and underground travel. Dramatic population growth as a consequence of the Industrial Revolution and the Empire's role explain go a long way in explaining these phenomena. In particular, the Greater London Area saw a spectacular swelling of its population, which doubled between 1880 and 1911. The London County Council's graph beneath shows the city's demographic evolution:

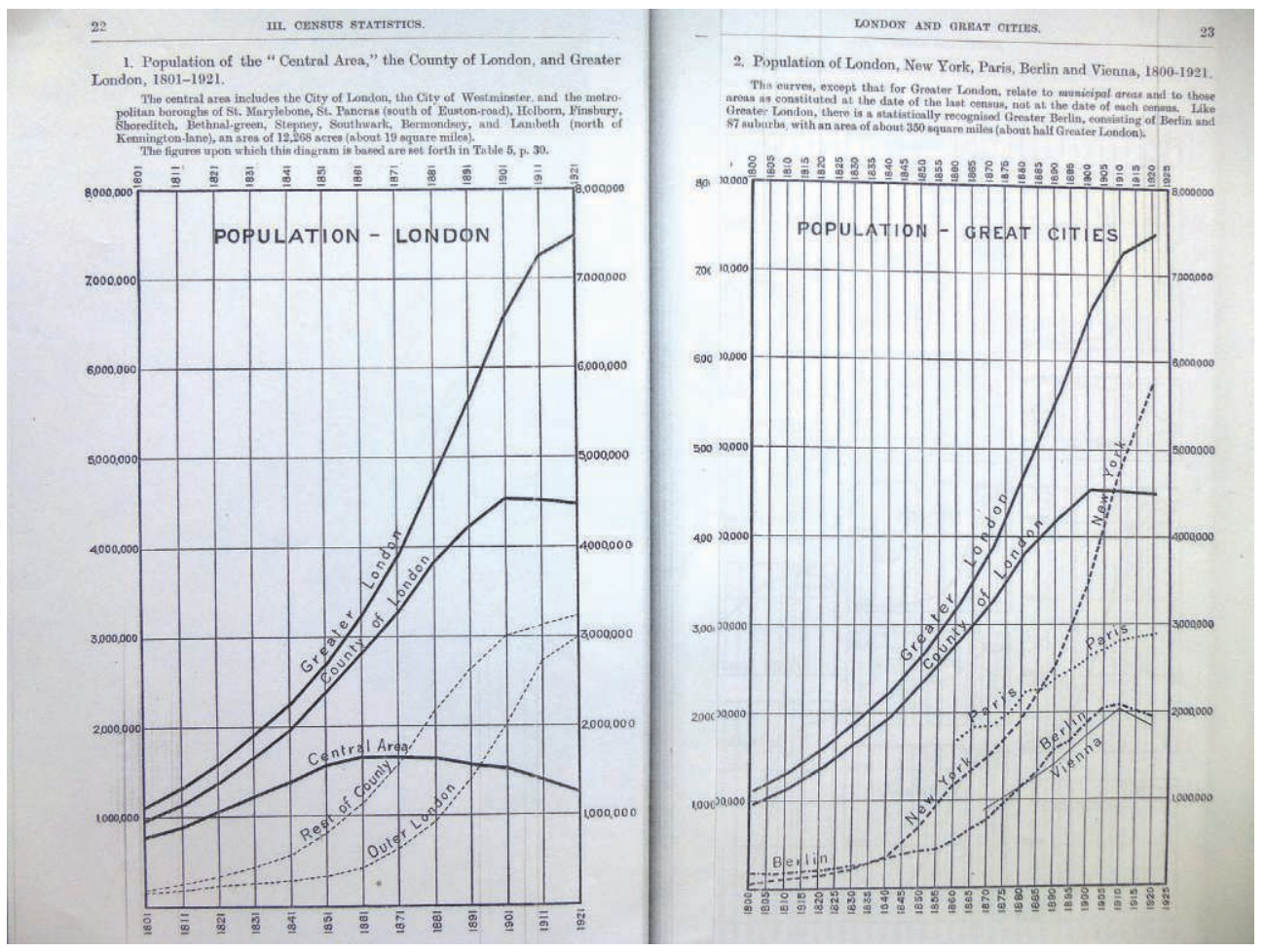

London Statistics 1915-20. (C) London County Council.

(Permission: Maps Section, Bodleian Library, University of Oxford)

The graph to the left compares the populations of Greater London, the County of London and the Central Area. While populations start to decline in the County and Central Areas of London from 1901 onwards, the Greater London area saw an important increase pushing its total number beyond 7 millions. The graph to the right sets Greater London and the County of London side by side with New York, Paris, Berlin and Vienna. Both London regions appear as the world's most populous during the Edwardian period, reflecting a trend to live in large metropolitan areas, a trend prevailing well into the twenty-first century. Moreover, the graph symbolizes the growing spatial importance of the Greater London area: the corresponding upward line representing London's population growth occupies a much larger space when compared to the Central Area.

The unprecedented population growth transformed settlement patterns around the country, resulting in a suburban expansion second to none. Barker observes in 
Edwardian London: "More important than any single Edwardian development was the suburban explosion" (81). In particular, London spread westward, eastward and northward, where "in the Finchley-Hendon area alone the number of houses rose by 14,000" (81). Developments to the east of London, for example, saw the construction of the Millbank Estate in 1907 and the Boundary Street Estate in Shoreditch to accommodate the increasing demands of working-class populations. The numbers from the 1911 Census by the L.C.C. show a sharp decline of the City population from 1901 to 1911. During the same period, the western suburbs of Fulham and Hammersmith, for instance, increased by $12 \%$ and $8 \%$ respectively, Hampstead's residents by $4 \%$, and the south-London area of Lewisham by $26 \% .{ }^{12}$ Although suburban growth clearly starts during the last decade of the Victorian age, population levels of the city's outer parts peak during the Edwardian years. Cleaner fresh air and a large number of green spaces acted as decisive factors in encouraging people to leave the inner core of London, and to settle in its outskirts. The result is a renewed sense of human spaces, which synthesize urban and suburban places, creating unheard-of spatial distributions of the population. Unprecedented spatial displacements and flows of people are another consequence of these changes.

These flows are made possible by transport systems literally erupting all over London. The Victorian era undoubtedly saw the proliferation of railway tracks around the country, linking the remotest rural areas to urban centres. The Edwardian era, on the other hand, witnessed an unseen intensification of underground railway lines, notably in London. In 1902, for example, the Underground Electric Railways Company of London (UERL) was established to provide electrification of the District line, and to complete three tube lines by 1906: Baker Street and Waterloo Railway, Charing Cross, Euston and Hampstead Railway, Great Northern, Piccadilly and Brompton Railway. It was, however, the Central London Railway - inaugurated by the Prince of Wales, the future King Edward VII, on 27 June 1900 - which became renowned as the key Edwardian transport achievement. The Central London Railway was the world's first metropolitan line to run completely underground in tunnels between Shepard's Bush in the west and the Bank of England in the City. The Line was later extended to Wood Lane in 1908, and in 1912 to Liverpool Street in the east. The success of the line was instantaneous, with almost 15 million passengers by the end of its inaugural year alone. ${ }^{13}$ The Central line exemplifies the strong demand for public transportation making the underground an Edwardian showcase. Moreover, the line connected various urban spaces through spaces created under ground. As a result, transportation in London reveals a sense of three-dimensionality, as populations incessantly move in underground tunnels between the centres and the suburbs.

Edwardian suburban growth necessitated further restructuring and streamlining of urban areas, in particular those of Greater London. The London Government Act of 1899, therefore, foresaw the creation of 28 metropolitan boroughs as sub-divisions of the county of London. The 13 March 1900 House of Commons sitting report listed the newly created boroughs:

12. For more information see: London County Council. London Statistics 1915-20.

13. See: <www.independent.co.uk/life-style/history/150-facts-for-150-years-of-the-london-tube-8444153.html> (05 January 2016) 
Copy presented, of Drafts of Orders in Council for the establishment of each of the undermentioned Metropolitan Boroughs, and incorporating the Council thereof, and for other purposes connected therewith: - Battersea, Bermondsey, Bethnal Green, Deptford, Fulham, Greenwich, Hackney, Hammersmith, Hampstead, Islington, Lambeth, Lewisham, Poplar, St. Marylebone, Shoreditch, Southwark, Stoke Newington, Wandsworth, and Woolwich [by Act]; to lie upon the Table. (HC Deb 13 March 1900 vol 80 c724)

With the Act, the former parliamentary boroughs of 1832 were dissolved in an attempt to replace vestries and district boards as part of local governments and to correct boundary anomalies across Greater London. The administrative alignment modernized the organization of the British metropolis, leading to an improved urban efficiency and management. New administrative spaces were created.

One last emblematic Edwardian phenomenon, leisure railway travel, brings this section on human geography to a conclusion. While sport and leisure activities developed towards the end of the Victorian period, the Edwardian years saw the emergence of long- distance recreational travel during a period often referred to as the Golden Age of Rail Travel. ${ }^{14}$ In Victorian and Edwardian Railway Travel, David Turner presents the railway as "One of the main modes of long distance travel" (1). Although Turner contrasts the preferred methods of travel during the two eras, he seems to disregard two singular Edwardian occurrences. The first concerns a development in recreational railway travel from London outwards to such notorious destinations as Edinburgh, Brighton, Bath and Cornwall. Populations living in the noisy, polluted and crowded City yearned for the tranquil, green and natural spaces of the countryside. The urban conditions necessitated the creation of spaces providing an alternative to the intensification of external and internal sensual stimuli provoked by the metropolis, a phenomenon Simmel refers to as "the intensification of nervous stimulation" (9). Faster railways made long-distance travel even more palpable. The journey from London to Edinburgh, for example, took just over six hours at the beginning of the twentieth century. The second phenomenon in leisure rail travel refers to a movement in the opposite direction: from the suburbs to the city centre. As a consequence of suburban growth, people living on the outskirts were now eager to reach the entertainment areas of Central London. These trends were facilitated by the new standards created in long-distance and underground railways. Moreover, they reflect the popularity of railway travel across a large spectrum of social classes with its processes of checking and reading timetables, buying tickets, taking a seat and waiting for trains. A genuine leisure railway culture resulted, and with it leisure travel. Some of the main stations in London like St Pancras and Victoria grew into truly modern transportation hubs. ${ }^{15}$ The long-distance recreational travel increased the sense of spatial expansion as new populations discovered regions previously inaccessible to them.

Focusing on human and physical aspects, the essay's two initial sections analysed the changing face of geographical spaces, which also influenced the emergence of geography as an interdisciplinary field, giving rise to the study of what came to be known as "geo-politics."

14. The Golden Age of Rail Travel is believed to have started with the Orient Express's inaugural journey from Paris to Constantinople in 1883.

15. It is quite interesting to note that St Pancras International has regained its status of an international transportation hub since the inauguration of the Eurostar services in 2007. 


\section{Edwardian Geo-Politics}

Geo-politics relies on physical and human dimensions of geography in order to make sense of political decisions within a renewed context of international relations at the beginning of the twentieth century. In Europe, in particular, relations between the great powers were changing in the years leading up to WWI, a period dominated by rivalries among powerful nations. Competition often stemmed from territorial disputes in which physical size and the location of national borders influenced international relations, particularly between France and Germany. During these years of political tension, the term "geo-politics" appeared for the first time in a scientific context with Emil Reich's Foundations of Modern Europe: Twelve Lectures Delivered in the University of London (1904).

Reich's set of lectures used "geo-politics" as a concept to link geography to politics: "History, in Europe, and still more outside Europe, is written largely, if not wholly, in characters of that geography, or, as we prefer to call it, geo-politics" (Reich 8). The Austro-Hungarian born historian saw geography as "the concrete cause" (8) in shaping political decisions, and privileges physical geography over politics. According to Reich, physical geography replaced racial distinctions on the European continent as the main source of conflictual relations: "It is high time that people studying history give up the untenable idea of 'race.' In Europe, at any rate, history is not made by 'races"' (223). Instead, according to Reich, the concrete dimensions of the great powers' territories had begun to shape policy-making: "At present day the forty-six sovereign states of Europe have each of them a continuous, so to speak, self-contained territory. This fact is of the utmost importance in international policy" (219). Reich saw the physical parameters of the European powers emerging as decisive variables in redesigning the political landscape in the wake of WWI.

Geo-political tensions before the outbreak of the war become strikingly apparent in Erskine Childer's The Riddle of the Sands (1903), one of the earliest espionage novels in English literature. The story is mainly set around Germany's East Frisian Islands, situated on its Northwestern coastline between The Netherlands and the Jutland Peninsula of Schleswig-Holstein. The area consists of constantly shifting tidal waters, referred to as the "Wadden Sea." Contemporary critics, notably David Seed, see the novel as "a tale of detection where the land itself becomes the source of the mystery" (118). More than just a source of mysteries, the Wadden area becomes central to the story as the distinctive relief shapes the narrative. Narrated in the first-person by the Foreign Office employee Charles Carruthers (Childer used a fictive name for the sake of caution), The Riddle of the Sands describes his sailing venture with Arthur Davies, a former college acquaintance, onboard their Dulcibello. Their trip takes them to the site of a rumoured secret treasure recovery project on Memmert Island, a small island in the Western part of East Frisia. Far from being a simple travel account, the tale rapidly evolves into what I choose to call "topographical espionage." This idea refers to a double spying phenomenon: the protagonists' secretive discovery of the sand banks spaces in the Wadden Sea, on the one hand, and their spying on Germany's covert clandestine political intentions organized around East Frisia's tidal waters on the other.

The protagonists' yachting cruise along the Frisian coast gradually surfaces as an exploration of local topographies. When confronted with the Sea's shifting sands and tidal waters, Carruthers struggles to understand the seemingly obscure landforms: "What's all this?" he wonders, when "running [his] finger over some dotted patches which co- 
vered much of the chart" (Childers 55). The dotted patches on his map represent the "bald spaces" of sand which appear at low tide, as his friend explains: "All sand,' said Davies, enthusiastically. 'You can't think what a splendid sailing-ground it is. You can explore for days without seeing a soul. These are the channels, you see; they're very badly charted"' (55). Inscribed since 2014 in the UNESCO World Heritage list, the region's intertidal zone consists of a string of sandy islands to the North and a space of strong tidal fluctuations in between the mainland and the Sea. The skill required to sail in such zones resides in detecting the navigational channels in order to avoid damages to the vessel. The chart presented below of the Juist, Memmert and Norderney islands maps the dotted patches of the booms along which navigation is possible.

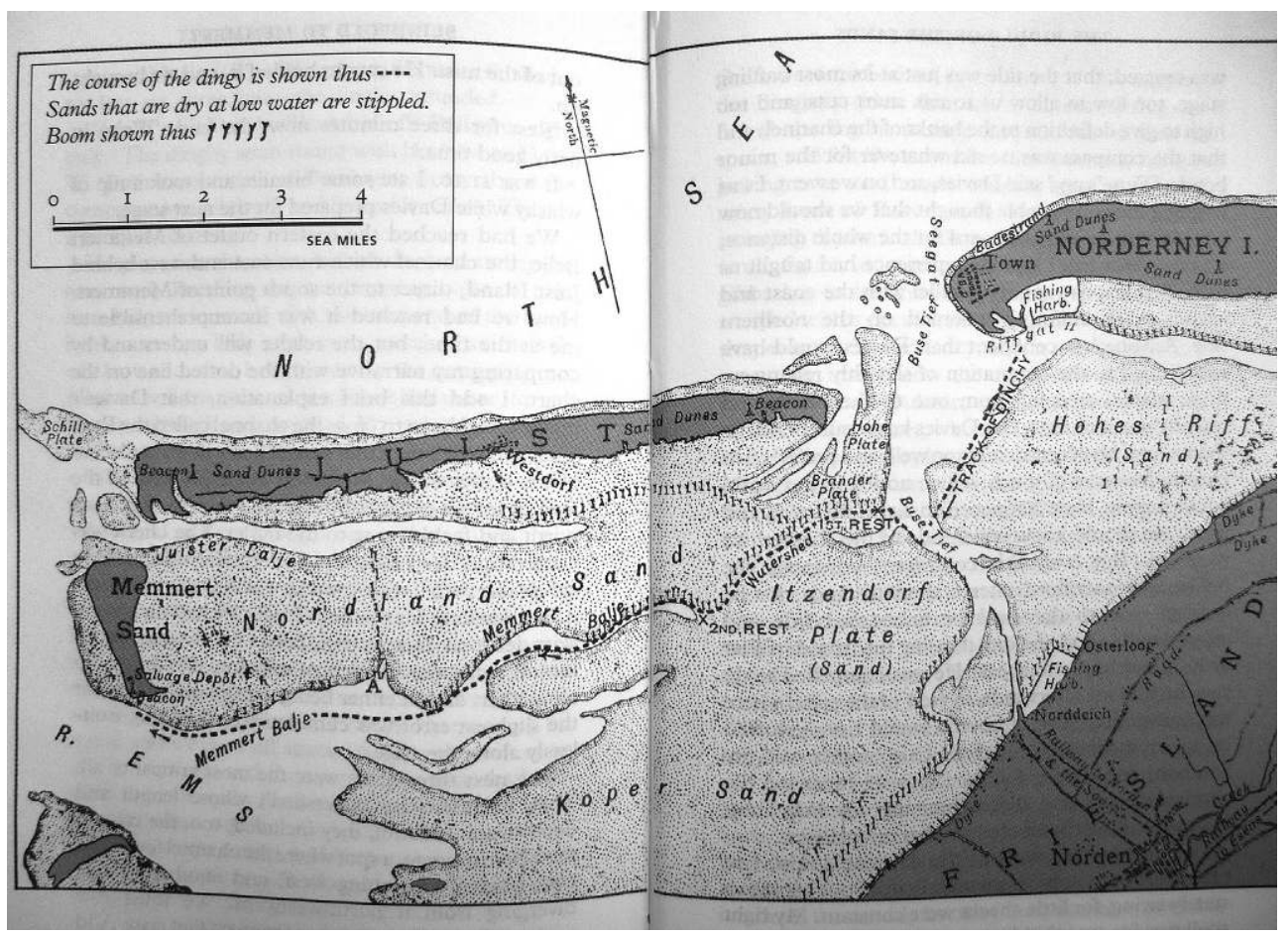

Erskine Childers. Chart B-Juist, Memmert, Norderney. (Permission requested from Adelaide University. )

The booms represent the navigational spaces on Childer's map; they furthermore refer to the real spaces of the terrain, the so-called "channels." The channels are the synthesis of concrete and representational spaces in the novel. Davis and Carruthers are quick in identifying these channels: 'I use the general word 'channel,' but in fact they differ widely in character, and are called in German by various names: Balje, Gat, Loch, Diep, Rinne" (140). Before long, Davies distinguishes between two distinctive types: "For my purpose I need only divide them into two sorts - those which have water in them at all states of the tide, and those which have not, which dry off, that is, either wholly or partly at low-tide" (140). The two sailors' understanding of the water- 
carrying channels turns out to be primordial because the fluctuations between ebb and flow provoke constantly shifting sands in the bays and estuaries along the Wadden coast with more or less strong watersheds. Watersheds are created by shifting sands which form high ridges between channels. Waters are shallow over the ridge and deeper away from the watershed.

The riddle of the sands stands for the deciphering of the enigma around the navigational channels to the side of the higher sand ridges when sailing over the banks: " $[\mathrm{W}]$ hen the ebb has run out and the flood begins, the channel is fed by two currents flowing to the centre and meeting in the middle" (143-4). Davies's observation of the watershed during periods of ebb and flow explains the Wadden Sea's underwater topography. Aided by Davies's maritime knowledge, Charles Carruthers then uncovers the usage of navigational channels by the local population, as the Frisians employ these waterways connecting the outer islands to the mainland coast. Furthermore, these channels appear to end in so-called siels, the German word for "sluice." When Carruthers locates seven corkscrew streams running to seven different sluices on the map, a mystery unfolds: "But it arrested my attention now because it looked more prominent than I should have expected. Charts are apt to ignore the geography of the mainland, except in so far as it offers sea-marks to mariners. [...] On the ordnance map it was marked with a dark blue line, was labelled 'Benser Tief"' (328). The German tief corresponds to a navigational canal created by a sluice (for their deep waters) and constitutes the prolongation of the maritime route inland. A total of seven siel-towns dot the Frisian coast, and form the "sevenfold system." Each of the seven port towns provides a sluice so that navigation is guaranteed in "passing from the interior to the islands" (329). In addition, the towns have direct railway links to Bremen and Hamburg, located further inland. The two amateur yachters' unravelling of the seven siels already represents no mean topographical feat in itself as their "geography was clear now" (273). Nonetheless, their private undercover work on East Frisia's unique topography produces a non-negligible side effect: the suspicion of sinister German activities.

The young yachters' suspicion is aroused when Davies is almost wrecked in rough waters by a ship driven by the double agent Dollmann at the beginning of the novel. The incident initially leads the sailor to ask his college friend to join him, as Davies has suspected covert German activities for a long time. Their suspicion is confirmed when both Davies and Carruthers now uncover the mastermind behind the plot: " $[\mathrm{H}]$ e's an Englishman in German service. He must be in German service, for he had evidently been in those waters a long time, and knew every inch of them" (104). The fact that "that chap was a spy" (97) does not deter Carruthers and Davies from starting their own espionage on the secret German operation. The result is a double espionage, as Herr Dollmann (his first name is never given in the novel) spies on the English, and the protagonists track down the Germans. The singular topography of the Wadden Sea lies at the centre of the German plot, a plot discovered by Davies and Carruthers when secretly listening to Böhme. The latter classifies the seven sluices from A to G in order to organise the invasion of the English shores "from the seven shallow outlets" (355). Through the sluices and then the channels, the Germans are able to invade England using the most sophisticated topographical features of the "daring scheme, under which every advantage, moral, material, and geographical, possessed by Germany, is utilized to the utmost, and every disadvantage of our own turned to account against 
us" (374). The geo-political dimension becomes evident when multitudes of seagoing lighters carrying full loads of soldiers in seven ordered fleets from seven shallow outlets and, under the escort of the German Imperial Navy, intend to cross the Sea to invade the eastern shore of England.

The Riddle of the Sands synthesizes private and national espionage into a topography of constantly shifting sands, an area far from being a stable space, and repeatedly being displaced as the narrative unfolds. The geographical space of East Frisia embodies the real protagonist in the novel and acts, to use Simmel's words, as the "outer and inner stimuli" (9). The dialogue of both "impressions" stimulates the protagonists in solving the riddle. The novel furthermore highlights what Klaus Dodds describes as "the power of agents and organizations to write over space, to occupy space, to organize space, and to create places invested with particular visions and projects" (5). Childer's story is believed to have influenced Winston Churchill's national and international geo-politics, and played a substantial role in the establishment of the Secret Service Bureau in 1909. ${ }^{16}$ The narrative sets a pattern for future spy thrillers as well, in that the novel combines the sub-genres of adventure novel and invasion story to create a modern spy mystery. Lastly, the Riddle corresponds to a literature located in geography as the geographical spaces shape storyline and characters alike.

\section{Fiction Inspired by Geography}

Our final example concerns geographically inspired fiction for which Forster, one of the most prolific Edwardian novelists, is a good example. ${ }^{17}$ The author portrays the changing face of England's spaces in an unprecedented fashion. From the Salisbury plains in The Longest Journey (1907), the counties of Hertfordshire and Shropshire in Howards End (1910), Cambridge and Somerset in Maurice (1913) to the Downs in A Room With a View (1908), ${ }^{18}$ Forster depicts a typical English countryside. The depictions of these landscapes are not entirely rural though. They are the result of mutual interactions between the city and the country. A prime example of the author's dialectical relationship of city and country remains Howards End.

As the title suggests, Howards End (1910) focuses on one specific place, notably Howards End. The fictive place in Hertfordshire figures as the theatrical scene where the lives of two families collide. The bourgeois Wilcoxes made their fortunes profiting from the Empire's trade relations. The German Schlegels represent the intellectual opposite through their embracing of liberal ideas. Matters become complicated when Helen Schlegel falls in love with Paul Wilcox, and when his mother, Mrs. Wilcox, dies leaving the estate to Margarete Schlegel. Mrs. Wilcox's attempt to bar her son's right of inheritance provokes Paul's outrage. Her decision though stems from Margarete's love for the place, namely Howards End. While most contemporary critics focus on the contrasting families - David Bradshaw, for instance, writes: "All of Forster's novels are

16. Additional information can be found in Ned Halley's "Afterword" to Childers's cited edition, 385-95.

17. Due to the relative brevity of the article, the analysis will be focused on Forster. Other important Edwardian literary productions include Walter Besant's The Fascination of London and F. M. Ford's The Soul of London (1905), Conan Doyle's The Hound of the Baskervilles (1902) and Conrad's The Secret Agent (1907).

18. Our study takes under consideration the second part of the novel as the first is mainly set in Tuscany. 
structured around contrasts, [...] and they also entrain for his idiosyncratic sphere of antitheses: North versus South; suburbia versus the country; the country versus the city [...]" (4) - the novel gravitates around Howards End. Howards End is not just another literary setting; it symbolizes a geographical locus that connects much more than two families:

The station for Howards End was at Hilton, one of the large villages that are strung so frequently along the North Road, and that owe their size to the traffic of coaching and pre-coaching days. Being near London, it had not shared in the rural decay, and its long High Street had budded out right and left into residential estates. [...] Beyond these tumuli habitations thickened, and the train came to a standstill in a tangle that was almost a town. The station, like the scenery, like Helen's letters, struck an indeterminate note. Into which country will it lead, England or Suburbia? (123)

The opposition between the urban and the rural disappears at Howards End, since the place bridges the gap between the city and the country. The speed with which the train connects Hilton with the city shortens the distance between the country and London as "the train sped northward, under innumerable tunnels" (12). The high-speed connection enhances the synergy between the capital and Howards End in what appears to be a novelty for Hilton: "It was new, it had island platforms and a subway" (13).

Forster establishes a connection not only between the city and the country, but also between the various parts of London itself through character depiction. Leonard Bast, coming from the lower-middle class, serves as an example here: "Leonard hurried through her [London] tinted corridors, very much part of the picture. His was a gray life" (104). In contrast to the Schlegels, who reside in the posh and upscale Wickham Place of central London, Leonard lives in the poor southern fringes of the town: "The habit was analogous to a debauch, an outlet, though the worst of outlets" (104). Through a rather complicated turn of events, Leonard loses his job as a clerk. Helen, flying to his help, has an affair with Leonard and becomes pregnant. A love relationship connecting not only different social classes but also metropolitan spaces is the consequence. The narration intertwines urban and suburban spaces through character portrayal, making them dependent on one another. Suburbia, however, is not reduced to London alone, as the rhetorical question in the above passage suggests. Howards End is the countryside which virtually becomes suburban. Even if Howards End "is one of those converted farms," (115), "the neighbourhood's getting suburban. Either be in London or out of it, I say" (115). Insisting on the place's residential allure, Paul Wilcox imagines Howards End to be London. Howards End thus connects with London, and London re-connects with Hertfordshire in what evolves as a metaphorical (sub)urban space.

These literary spaces reflect Edwardian trends, in that London epitomizes the rapidly changing metropolis around the turn of the last century. The "precious soil of London" (Forster 6) soon emerges as the author's favoured landscape: "To speak against London is no longer fashionable. The earth as an artistic cult has had its day, and the literature of the near future will probably ignore the country and seek inspiration from the town" (92). Certainly "London fascinates" (92) as "London was beginning to illuminate herself against the night. Electric lights sizzled and jagged in the main thoroughfares, gas lamps in the side-streets glimmered a canary gold or green" (104). Impressions such as the electric light and the gas lamps recall Simmel's "psychological conditions which the metropolis creates" (9). Forster's novel underlines these psychological conditions, em- 
phasizing the ways in which the London metropolis enhances consciousness, something which is not possible in a rural context.

In Howards End, Forster dialectically combines the antitheses of city and country, of the urban and the suburban, to elevate settings into the realm of geographicallyinspired spaces. The synthesis of both, Howards End and London, creates a spatial aura representative of Edwardianism as human geographies (the suburban expansion, railway travel, population growth) merge with the physical landforms of Hertfordshire, Shropshire and London, foreshadowing modernist trends, in which the city will become the literary locality, notably in Virginia Woolf's oeuvre.

Forster writes that Howards End is "enlarging the space" (160). More than just enlarging the sense of space, geographies turn spatial during the Edwardian years. The relative brevity of the era should, therefore, be no excuse for an absence of awareness of the geo-critical spaces it invents, transforms and displaces. After all, geo-morphological features, meteorological phenomena, human developments, geo-political implications and literary depictions mirror renewed conceptions and perceptions of spaces. These Edwardian spaces laid the foundations for pioneering apprehensions of geography, which subsequently influenced later Modernist understandings of an ever-changing geographical world. Hence, geography's spatial turn during the Edwardian era fulfilled a pertinent function in guaranteeing the link between the Victorian and Modernist periods.

Andreas Pichler Aix Marseille University

\section{Works Cited}

BAGNOLD, Ralph Alger. "Journeys in the Libyan Desert, 1929 and 1930.” The Geographical Journal 78.1 (1931): 13-39.

BARKER, Felix. Edwardian London. London: Laurence King, 1995.

BRADshaw, David. The Cambridge Companion to E. M. Forster. Cambridge: Cambridge UP, 2007.

Brooker, Peter, and Andrew ThaCKer, eds. Geographies of Modernism: Literatures, Cultures, Spaces. Oxon: Routledge, 2005.

Bulson, Eric. Novels, Maps, Modernity: The Spatial Imagination, 1850-2000. London: Routledge, 2006.

Childers, Erskine. The Riddle of the Sands. 1903. London: Collector's Library, 2008.

Collot, Michel. Pour une géographie littéraire. Paris: Editions Corti, 2014.

DodDs, Klaus. Geopolitics. Oxford: Oxford UP, 2014.

DünNE, Jorg, and Stephan GüNZEL. Raumtheorie: Grundlagentexte aus Pbilosophie und Kulturwissenschaften. Frankfurt am Main: Suhrkamp, 2006.

Forster, Edward Morgan. Howards End. 1910. London: Penguin, 2000.

—. The Longest Journey. 1907. London: Penguin, 2007.

—. A Room With a View. 1908. London: Penguin, 2011.

—. Maurice. 1971. London: Penguin, 2005.

FreEmAn, Nicholas. Conceiving the City: London, Literature, and Art 1870-1914. Oxford: Oxford UP, 2007.

Herbertson, Andrew John. "The Major Natural Regions: An Essay in Systematic Geography." The Geographical Journal 25.3 (March 1905): 300-10.

-. Man and His Work: An Introduction to Human Geography. London: Adam \& Charles Black, 1899.

Humboldt, Alexander von. Schriften zur Geograpbie der Pfanzen. 1805. Darmstadt: Wissenschaftliche Buchgesellschaft, 1987.

Kemp, Sandra, Charlotte Mitchell, and David Trotter, eds. The Oxford Companion to Edwardian Fiction. Oxford: Oxford UP, 2007.

London County Council. London Statistics 1915-20. Vol. 26. London County Hall, Spring Gardens: 1921. 
Mackinder, Halford J. “The Geographical Pivot of History.” The Geographical Journal 23.4 (April 1904): 421-37.

Mighall, Robert. A Geography of Victorian Gothic Fiction: Mapping History's Nightmares. Oxford: Oxford UP, 1999.

MoretTi, Franco. Atlas of the European Novel 1800-1900. London: Verso, 1998.

NAYLOR, Simon. Regionalizing Science: Placing Knowledge in Victorian England. London: Pickering \& Chatto, 2010.

ReICH, Emil. Foundations of Modern Europe: Twelve Lectures Delivered in the University of London, 1904. London: George Bell \& Sons, 1904.

Saunders, Max. "Ford, the City, Impressionism and Modernism." Ford Madox Ford and the City. Ed. Sarah Haslam. Amsterdam: Rodopi, 2005. 67-80.

SeED, David. "Spy fiction." The Cambridge Companion to Crime Fiction. Ed. Martin Priestman. Cambridge: Cambridge UP, 2003. 115-34.

Simmel, Georg. Die Großstädte und das Geistesleben. 1903. Frankfurt am Main: Suhrkamp, 2006.

THACKer, Andrew. Moving through Modernity. Manchester: Manchester UP, 2003.

Turner, David. Victorian and Edwardian Railway Travel. London: Shire, 2013.

WestPhal, Bertrand. Geocriticism: Real and Fictional Spaces. Trans. Robert T. Tally, Jr. London: Palgrave Macmillan, 2011. Trans. of La Géocritique: Réel, Fiction, Espace. Paris: Minuit, 2007.

Whiтtow, John B. Dictionary of Physical Geography. London: Penguin, 2000.

WoOdward, Horace B. History of Geology. London: Watts, 1911.

\section{Websites}

<http://global.britannica.com/EBchecked/topic/134929/continental-landform/49819/Davisserosion-cycle-theory-and-related-concepts $>$ (05 January 2016)

$<$ http://www.bgs.ac.uk/about/ourPast.html> (05 January 2016)

$<$ www.independent.co.uk/life-style/history/150-facts-for-150-years-of-the-london-tube-8444153. html> (05 January 2016)

\section{List of Illustrations}

Figure 1: Geological Map of Great Britain by Horace B. Woodward. London: Stanford, 1912.

Figure 2: Population of the "Central Area," the County of London, and Greater London, 1801-1921, London County Council 1921.

Figure 3: Chart of Juist, Memmert and part of Norderney. Erskine Childers. The Riddle of the Sands. London: Collector's Library, 2008. 262-3. 